$1 \mathrm{D}-07$

\title{
安全教育の効果測定に関する基礎研究一III
}



A Study of Measurements for Safety Educational Effects (III)

M. Masada (Rikkyo University) OM. Fujiie - K. Muto (Tokyo Electric Power Company)

1.はじめに

第 1 報、第 2 報で述べたとおり、原子力発 電所の遇転貣を対象として、よりよい安全教 育を行うことを目的に、安全教育の効果测定 の研究を実施している。

今回は、現在までに得られた結果の一部に ついて、その概要を報告する。

\section{2. 概略}

原子力発電所の運轱员を対象に、(1安全性 格検査、(2)安全隹度調査、(3)集団分囲気調査、 (4) N R K方式セーフティーマネージメント診 断、の4つの朤查を実施し、その結果をつィ 一ドバックすることにより安全教有を実施し た。また、フィードバックは、4チームに 3 通りの方法で実施した。

(2の安全悲度調查は、各々 11 項目からな るAスケールと、Bスケール（表 1 智照)で 構成されており、教育の前後で安全稳度值を 湖定し教育の効果をみた。

本報では、この結果を中心に報告するもの である。

3. 結果

1) 位 (グループ) 別安全稳度の変化
原子力発電所の運転月は、当直長、当直副 長、主任、即主任、主機操作員、補機操作只、 により粠成されている。そしてその仕事内容 は、諓位によって異なっている。そこで、 (a) 管理的職位である当直長・当直副長、

（b）通転操作の中心となる主任・主機操作 是、（c）パトロールなど現場ワークが多い


ルーフト分け、安全堭度の変化の差を見た （表 2 参照）。

2 ) フィードバック別安全惉度の変化

先に述べたとおり、フィードパックは３通 りの方法で実施した。（a）対面フィードパ ック 2 回、（b）対面フィードパック 1 回、

（c）交料の送付のみ、といったフィードバ ックの相进による、安全稳度の変化の差をみ た（表 3 參照）。

また、安全稳度得点により被鏂者を 3 群に 分け（成䋩の良い湴に、GOOD群、MED I U M群、POOR群）、全体に占める人数 の推移をみた（表 4 参照）。

本結果を踏まえ、さらに詳細な分析を行い、 尺度つくり、安全教育の体系化につなげてい $<$ 。 




州：氐各

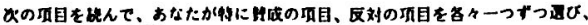


1 タハコをナいなから服を道枟しない
2 แ下には、ワックスを十分にぬる



 をヤかる
5 スケートをナるとをは、必で手皦はめる


7 ストーフのまわりにかこいをしておきさえすれは、子件がストーフの近 くへ行ってb航くくな










盾：代名








